\title{
Analisis Laju Distribusi Cemaran Kadmium (Cd) di Perairan Sungai Jeneberang Kabupaten Gowa
}

\section{Analysis of the Distribution Rate of Cadmium (Cd) Contamination in the Jeneberang River Waters of Gowa}

\author{
Masriadi, Program Studi Pendidikan Teknologi Pertanian Fakultas Teknik, Universitas \\ Negeri Makassar.Email: masriadiagro@gmail.com \\ Patang, Program Studi Pendidikan Teknologi Pertanian Fakultas Teknik, Universitas Negeri \\ Makassar. Email: \\ Ernawati, Program Studi Pendidikan Teknologi Pertanian Fakultas Teknik, Universitas \\ Negeri Makassar. Email:
}

\begin{abstract}
Abstrak
Limbah umumnya banyak mengandung logam berat seperti kadmium $(\mathrm{Cd})$ yang dapat mencemari lingkungan terutama di wilayah perairan. Tujuan dari penelitian ini untuk mendapatkan data dan informasi cemaran logam berat kadmium $(\mathrm{Cd})$ di perairan sungai Jeneberang kabupaten Gowa dan pengaruh kadmium terhadap kualitas air dengan parameter suhu, $\mathrm{pH}$ dan oksigen terlarut (DO). Penelitian ini merupakan jenis penelitian deskriktif dengan menggunakan metode survei, penelitian ini dilakukan dengan mengambil sampel air, ikan dan tanah pada lima lokasi stasiun berbeda yakni, stasiun 1 di daerah hulu sungai, stasiun 2 di sekitar bendungan Bili-bili, stasiun 3 di sekitar Jembatan Kembar Kabupaten Gowa, stasiun 4 di daerah hilir sungai dan stasiun 5 di sekitar pantai Losari Makassar. Hasil penelitian ini menunjukkan bahwa pencemaran logam berat kadmium $(\mathrm{Cd})$ pada air, tanah dan ikan hasil tangkapan di perairan sungai Jeneberang kabupaten Gowa masih dibawah dari nilai ambang batas yang menandakan bahwa perairan sungai Jeneberang masih belum tercemar kadmium (Cd). Parameter kualitas air tersebut yang meliputi suhu, $\mathrm{pH}$ dan oksigen terlarut (DO) masih pada batas yang sesuai untuk kehidupan organisme perairan yaitu 6,24-7,2 mg/L.
\end{abstract}

Kata Kunci: Distribusi, kadmium, perairan, sungai.

\begin{abstract}
Waste generally contains a lot of heavy metals such as cadmium $(C d)$ which can pollute the environment, especially in waters. The purpose of this study was to obtain data and information on cadmium $(C d)$ heavy metal contamination in the waters of the Jeneberang river in Gowa district and the effect of cadmium on water quality with parameters of temperature, $\mathrm{pH}$ and dissolved oxygen (DO). This research is a descriptive type of research using the survey method, this study was conducted by taking samples of water, fish and soil at five different station locations, namely station 1 in the upstream area of the river, station 2 around the Bili-bili dam, station 3 around the Bridge Gowa Regency Twin, station 4 in the downstream area of the river and station 5 around the Losari coast of Makassar. The results of this study indicate that cadmium $(C d)$ heavy metal contamination in water, soil and fish caught in the waters of the Jeneberang river in Gowa district is still below the threshold value which indicates that the waters of the Jeneberang river are not yet cadmium $(C d)$. The water quality parameters which include temperature, $\mathrm{pH}$ and dissolved oxygen $(D O)$ are still at the appropriate limits for the life of waters organisms is 6,24-7,2 mg/L.
\end{abstract}

Keywords : Distribution, cadmium, waters, rivers. 


\section{Latar Belakang}

Perkembangan industri di Sulawesi Selatan dewasa ini cukup pesat. Peningkatan jumlah industri ini diikuti oleh penambahan jumlah limbah, baik berupa limbah padat, cair maupun gas. Limbah tersebut mengandung bahan kimia yang beracun dan berbahaya (B3) dan masuk ke perairan sungai-sungai yang ada di Sulawesi Selatan (Anggriana, 2011) salah satunya adalah Sungai Jeneberang. Sungai Jeneberang sebagai daerah penelitian berasal dan mengalir dari Gunung Bawakaraeng dan Gunung Lompobattang yang kemudian menuju hilirnya di Selat Makassar.

Air Sungai Jeneberang merupakan air yang banyak dimanfaatkan untuk kebutuhan masyarakat sekitar daerah aliran sungai. Proses pengaliran air Sungai Jeneberang akan menerima berbagai macam sumber pencemar yang masuk ke badan air sehingga menyebabkan kualitas air sungai menurun (Taufieq, 2009). Menurut Alamsyah (1999) dalam Patang (2009) pencemaran lingkungan pesisir dan laut dapat diakibatkan oleh limbah buangan kegiatan atau aktivitas di daratan (land based pollution) maupun kegiatan atau aktivitas di lautan (Sea based poluution).

Tekanan lingkungan yang dirasakan antara lain turunnya kualitas air lingkungan karena limbah yang dihasilkan seluruhnya akan masuk ke perairan pesisir sungai Jeneberang. Kualitas air dapat secara luas didefinisikan sebagai faktor-faktor fisik, yang mempengaruhi penggunaan air kimia dan biologis untuk dimanfaatkan oleh manusia baik secara langsung maupun tidak langsung (Patang, 2014).

Limbah dari kandungan pestisida yang dibuang ke sungai Jeneberang dari daerah hulu dan tingginya tingkat pencemaran air yang bersumber dari pembuangan limbah dari daerah hilir sungai menyebabkan akumulasi yang berpotensi mengakibatkan gangguan kesehatan pada masyarakat di daerah hilir (Monoarfa, 2002). Menurut Ayyub $d k k$ (2018) Pencemaran dan sedimentasi tinggi terjadi akibat suplai dari daerah aliran sungai terutama oleh aktifitas penambangan, pertanian maupun oleh limbah rumah tangga.

Logam berat yang ada pada perairan, suatu saat akan turun dan mengendap pada dasar perairan, membentuk sedimentasi dan hal ini akan menyebabkan biota laut yang mencari makan di dasar perairan (udang, kerang, dan kepiting) akan memiliki peluang yang sangat besar untuk terkontaminasi logam berat tersebut (Feberiyanti, 2012 dalam Amansyah \& Alwiyah, 2014). Jika biota laut yang telah terkontaminasi logam berat tersebut dikonsumsi, dapat merusak sistem biokimia, dan merupakan ancaman serius bagi kesehatan manusia dan hewan (Khan $d k k, 2009$ dalam Setiawan, 2014).

Penelitian ini berusaha mengkaji distribusi logam berat kadmium (Cd) pada berbagai lokasi di aliran sungai Jeneberang. Logam berat kadmium (Cd) dipilih karena masih kurangnya pemahaman masyarakat mengenai bahayanya dan diharapkan dapat memberi kontribusi bagi berbagai pihak, baik di kalangan pemerintah, pihak swasta pengemban industri maupun masyarakat, terutama yang terkait dengan upaya peningkatan kesehatan bagi masyarakat yang tinggal di sekitar Sungai Jeneberang Kabupaten Gowa. 


\section{Bahan dan Metode}

\section{Bahan dan Alat}

Adapun bahan digunakan pada penelitian ini yaitu sampel air, tanah, ikan, nitrat (HNO3), aquadest steril serta bahan untuk menganalisis kadmium $(\mathrm{Cd})$ pada air, tanah dan ikan.

Peralatan yang digunakan dalam penelitian ini yaitu Atomic Absorption Spectrophotometric (AAS), termometer, $\mathrm{pH}$ meter, DO meter, botol sampel, alat tulis menulis, kertas saring whatman no. 42 mikron dan alat-alat gelas yang umum digunakan dalam laboratorium kimia serta peralatan untuk mengambil dan menyimpan sampel berupa pipa paralon $3 / 4$ inci, kantong plastik, botol sampel dan cool box.

\section{Jenis Penelitian dan Desain Penelitian}

Penelitian yang akan dilaksanakan adalah Explanatory Research atau penelitian kuantitatif dengan menggunakan metode deskriptif kuantitatif. Metode penelitian deskriptif dalam penelitian ini digunakan untuk menggambarkan hubungan antara cemaran logam berat pada air, tanah dan ikan yang berasal dari perairan sungai Jeneberang yang dimulai dari hulu sampai hilir sungai.

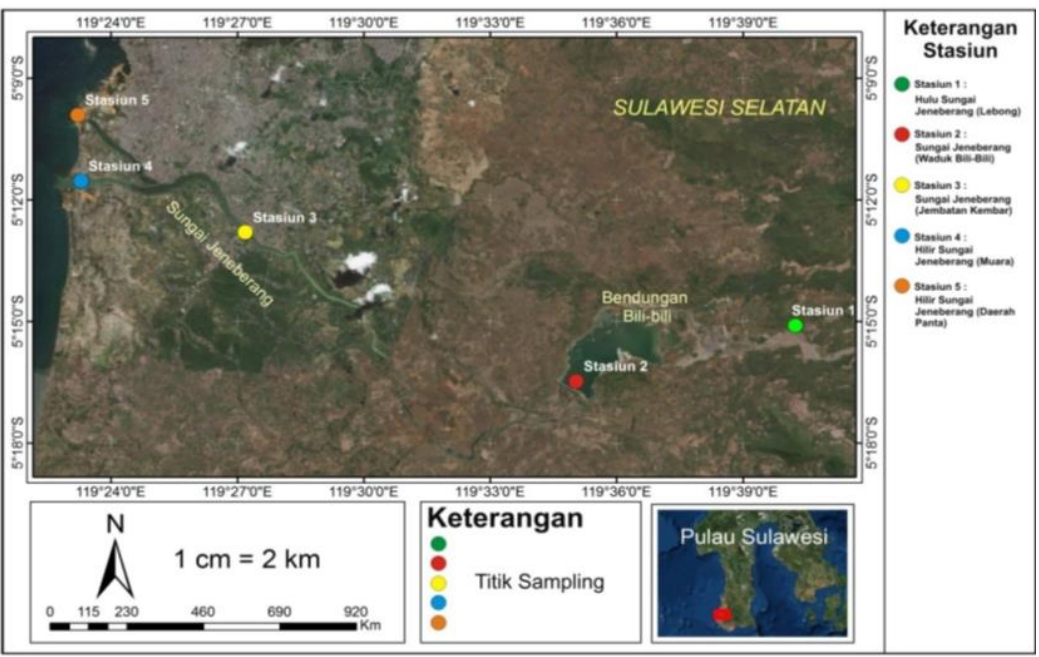

Gambar 1. Peta lokasi pengambilan sampel

\section{Pelaksanaan Penelitian}

Penelitian ini dilakukan dengan terlebih dahulu melakukan observasi di sepanjang aliran sungai Jeneberang, kemudian selanjutnya ditentukan parameter yang akan diteliti yaitu analisis kualitas air, tanah dan logam berat kadmium (Cd) pada daging ikan yang ditangkap di sungai Jeneberang.

Pengambilan daerah sampel dilakukan dengan melihat dan menduga lokasi-lokasi tersebut rentang terhadap penyebaran logam $\mathrm{Cd}$ seperti muara sungai, pelabuhan, daerah pertambakan, padang lamun, hutan mangrove, serta lokasi industri dan daerah yang diduga banyak terdapat buangan rumah tangga yang dapat menjadi sumber pencemaran logam $\mathrm{Cd}$.

Pengamatan ataupun pemeriksaan yang akan dilakukan terhadap sampel air, sampel ikan dan sampel tanah pada perairan sungai Jeneberang yang diambil pada lima titik lokasi stasiun yang berbeda serta dengan frekuensi pengukuran parameter kualitas air pada pagi hari mulai dari jam 06.00-10.00 WITA. 
JPTP Jurnal Pendidikan Teknologi Pertanian

\section{Hasil dan Pembahasan}

\section{Suhu}

Hasil penelitian menunjukkan suhu air yang diukur menggunakan termometer pada stasiun 1 dengan rata-rata $26^{\circ} \mathrm{C}$, stasiun 2 dengan rata-rata $28,6^{\circ} \mathrm{C}$, stasiun 3 dengan rata-rata $28,8^{\circ} \mathrm{C}$, stasiun 4 dengan rata-rata $28,6^{\circ} \mathrm{C}$ dan stasiun 5 dengan ratarata $29,6^{\circ} \mathrm{C}$.

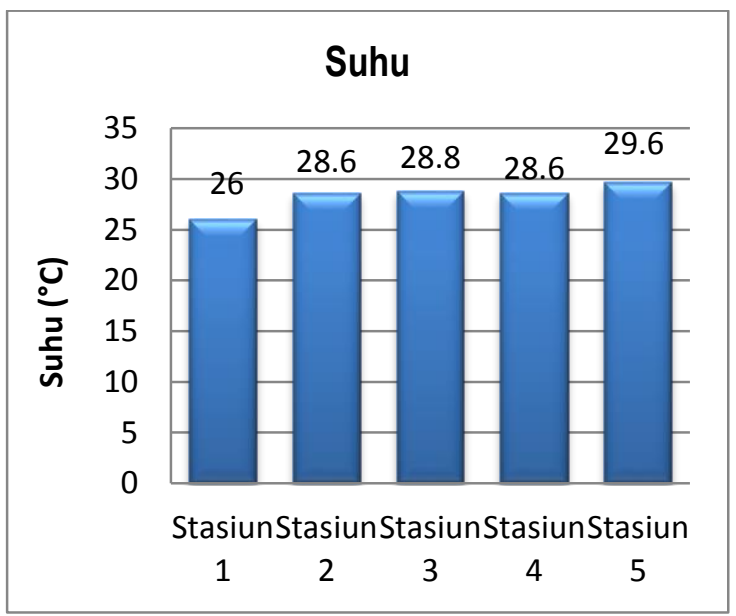

Gambar 2. Suhu pada Setiap Stasiun

Hasil pengukuran suhu di sungai Jeneberang memperoleh nilai rata-rata suhu pada setiap stasiun berkisar antara $26-30^{\circ} \mathrm{C}$, kondisi ini masih dalam taraf normal sesuai standar mutu kualitas air menurut Menteri Lingkungan Hidup Tahun 2004. Hal ini sejalan dengan pendapat Rina (2012) dalam Rachmaningrum $d k k$ (2015), kisaran suhu air yang baik dalam perairan dan kehidupan ikan yaitu berkisar antara $23-32^{\circ} \mathrm{C}$. Dimana pada penelitian ini suhu yang paling rendah yaitu pada stasiun 1 kemudian stasiun 2,4 , 3 dan 5. Perbedaan suhu pada setiap stasiun berbeda-beda karena dipengaruhi oleh banyak hal seperti waktu pengukuran serta kondisi lingkungan sekitar di setiap stasiun. Menurut Nurfitriani $d k k$ (2017) perbedaan suhu disebabkan oleh cuaca cerah/panas dan daerah tersebut lapang atau tidak adanya penutupan tumbuhan mangrove
Volume 5, 2019

sehingga matahari melepaskan panasnya dengan sempurna.

Berdasarkan analisa regresi linear berganda, bahwa kadmium (Cd) tidak memberikan pengaruh nyata $(\alpha=0,05$ dan $\alpha=0,01)$ terhadap suhu setiap stasiun perairan sungai Jeneberang dimana nilai $F$ hitung (2,790). Koefesien korelasi $(\mathrm{R})=$ 0,558 menunjukkan hubungan antara variabel bebas $(\mathrm{X})$ dan terikat $(\mathrm{Y})$ adalah positif. Koefesien determinan $\left(\mathrm{R}^{2}\right)=0,311$ menunjukkan pengaruh kadmium $(\mathrm{Cd})$ terhadap suhu hanya sebesar $31,1 \%$ dan sisanya $68,9 \%$ ditentukan oleh faktor lain yang tidak dianalisis pada penelitian ini. Suhu didalam perairan sebenarnya mempengaruhi proses kelarutan akan logam berat yang masuk ke dalam suatau perairan. Jika semakin tinggi suhu perairan maka kelarutan logam berat akan semakin tinggi pula (Wardhana, 2004 dalam Eshmat $d k k$, 2014). Menurut Happy $d k k$ (2012) faktor suhu juga mempengaruhi konsentrasi logam berat di kolom air atau sedimen, kenaikan suhu air yang lebih dingin akan memudahkan logam berat mengendap ke sedimen. Sementara suhu yang tinggi, senyawa logam berat akan larut dalam air. Suhu di perairan sungai Jeneberang masih dalam tingkat optimal yang menandakan logam berat pada kolom air tidak toksik.

\section{Derajat Keasaman (pH)}

Tingkat keasaman $(\mathrm{pH})$ yang diukur menggunakan $\mathrm{pH}$ meter pada stasiun 1 dengan rata-rata 7,26, stasiun 2 dengan rata-rata 7,52, stasiun 3 dengan rata-rata 6,5, stasiun 4 dengan rata-rata 7,26 dan stasiun 5 dengan rata-rata 7,56. 


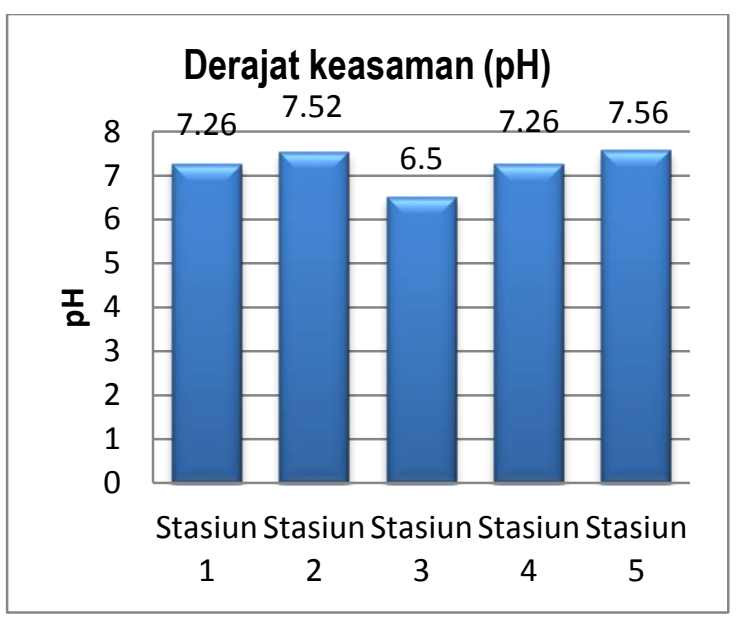

Gambar 3. pH pada Setiap Stasiun

Dari data hasil penelitian menunjukan nilai rata-rata $\mathrm{pH}$ pada setiap stasiun menunjukkan bahwa kisaran $\mathrm{pH}$ masih pada taraf yang normal yakni 6,57,56 sesuai dengan pedoman baku mutu lingkungan menurut Surat Keputusan Menteri Lingkungan Hidup Nomor : 51 Tahun 2004 yang menyatakan $\mathrm{pH}$ normal berkisar antara 6,5-8,5.

Konsentrasi $\mathrm{pH}$ yang paling rendah yaitu pada stasiun ke-3 yakni dengan nilai rata-rata 6,5 yang berarti bersifat asam, kemudian disusul oleh stasiun 1, 4, 2 dan 5. Dimana pada stasiun ini dipengaruhi oleh adanya keramba jaring apung serta pembuangan limbah industri rumah tangga di pinggiran sungai. Hal ini sesuai pendapat Yuningsih $d k k$ (2014) Keramba Jaring Apung (KJA) memiliki komposisi bahan organik yang tinggi dapat disebabkan karena kontribusi limbah dari pakan ikan yang terdapat pada KJA. Bahan organik berupa kotoran dan sisa pakan. Komposisi bahan organik dapat menyebabkan menurun atau meningkatkan $\mathrm{pH}$ air, hal ini dapat diterjadi karena pada proses dekomposisi bahan organik dapat menghasilkan asam. Menurut Nurdin (2009) dalam Wanna $d k k$ (2017) pada umumnya nilai $\mathrm{pH}$ di perairan rendah bersamaan dengan rendahnya kandungan mineral yang ada atau sebaliknya.

Berdasarkan analisis regresi linear berganda, bahwa kadmium $(\mathrm{Cd})$ tidak memberikan pengaruh nyata $(\alpha=0,05$ dan $\alpha=0,01)$ terhadap $\mathrm{pH}$ di setiap stasiun perairan sungai Jeneberang dimana nilai $\mathrm{F}$ hitung $(1,616)$ lebih kecil dari $\mathrm{F}$ tabel 5\% $(3,07)$. Koefesien korelasi $(\mathrm{R})=0,433$ menunjukkan hubungan antara variabel bebas (X) dan terikat (Y) adalah positif. Koefesien determinan $\left(\mathrm{R}^{2}\right)=0,188$ menunjukkan pengaruh kadmium $(\mathrm{Cd})$ terhadap suhu hanya sebesar $18,8 \%$ dan sisanya $81,2 \%$ ditentukan oleh faktor lain yang tidak dianalisis pada penelitian ini.

Adapun hal yang akan memberikan dampak cemaran logam berat menurut Palar (2004) dalam Nurdin (2009) bahwa pada $\mathrm{pH}$ rendah kelarutan logam berat akan meningkat. Dibuktikan dengan penelitian Al Husainy $d k k$ (2014) dengan hasil penelitian menunjukan semakin tinggi nilai $\mathrm{pH}$ akan menurunkan nilai kandungan logam berat dalam perairan. Sebaliknya semakin rendah nilai $\mathrm{pH}$ atau di bawah nilai 6 akan meningkatkan kelarutan logam berat. Selanjutnya toksisitas logam akan meningkat pada $\mathrm{pH}$ rendah dan sebaliknya peningkatan $\mathrm{pH}$ air akan menurunkan kelarutan logam berat (Syamsuddin, 2014).

\section{Dissolved Oxygen (DO)}

Dissolved Oxygen (DO) yang diukur menggunakan DO meter pada stasiun 1 dengan rata-rata $6,24 \mathrm{mg} / \mathrm{L}$, stasiun 2 dengan rata-rata $6,96 \mathrm{mg} / \mathrm{L}$, stasiun 3 dengan rata-rata 67,14 $\mathrm{mg} / \mathrm{L}$, stasiun 4 dengan rata-rata $7,06 \mathrm{mg} / \mathrm{L}$ dan stasiun 5 dengan rata-rata $7,2 \mathrm{mg} / \mathrm{L}$. 
JPTP Jurnal Pendidikan Teknologi Pertanian

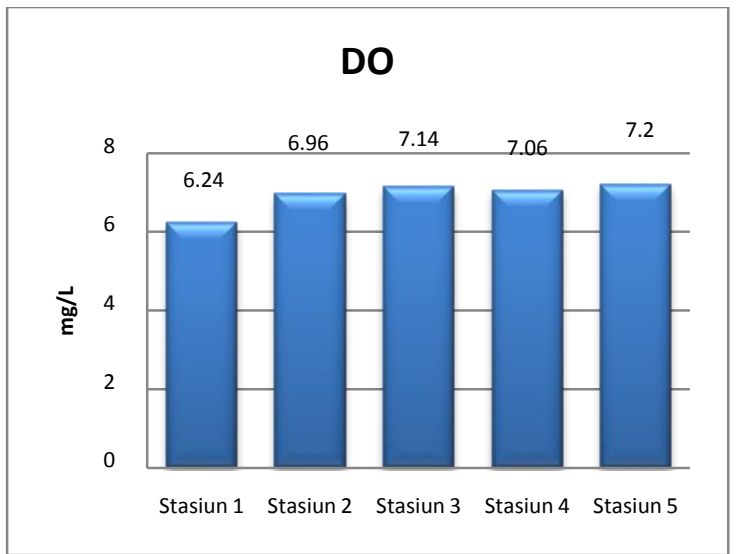

Gambar 4. Dissolved Oxygen (DO) pada Setiap Stasiun

Berdasarkan data hasil penelitian menunjukan nilai rata-rata DO pada setiap stasiun menunjukkan bahwa kisaran DO masih pada taraf yang normal yaitu 6,247,2 $\mathrm{mg} / \mathrm{L}$ sesuai dengan kriteria mutu air kelas III (PP RI No. 82 Tahun 2001) yaitu minimum $3 \mathrm{mg} / \mathrm{L}$. Semakin tinggi kadar oksigen terlarut dalam perairan mengindikasikan bahwa perairan tersebut kaya akan kandungan oksigen didalamnya sehingga baik untuk kehidupan biota perairan. Suatu perairan dapat dikatakan baik jika tingkat pencemaran yang rendah dengan kadar oksigen terlarutnya (DO) lebih besar dari $5 \mathrm{mg} / \mathrm{L}$ (Salmin, 2005 dalam Mahyudin \& Tri, 2015). Menurut Effendi (2003) kadar oksigen terlarut dalam perairan alami biasanya kurang dari 10 mg/L. Jika dibandingkan dengan hasil pengukuran nilai oksigen terlarut pada penelitian ini yang memiliki nilai DO 6-7 $\mathrm{mg} / \mathrm{L}$ masih tergolong perairan yang baik dan rendah tingkat pencemarannya.

Fardiaz (1992) dalam Nur $d k k$ (2016), menyatakan bahwa kejenuhan oksigen dalam air dipengaruhi oleh suhu air, semakin tinggi suhu maka konsentrasi oksigen terlarut semakin turun.

Berdasarkan analisa regresi linear berganda, bahwa kadmium (Cd) tidak
Volume 5, 2019

memberikan pengaruh nyata ( $\alpha=0,05$ dan $\alpha=0,01)$ terhadap DO dimana nilai $F$ hitung $(2,964)$ lebih kecil dari $F$ tabel $5 \%$ (3,07). Koefesien korelasi $(\mathrm{R})=0,583$ menunjukkan hubungan antara variabel bebas (X) dan terikat (Y) adalah positif. Koefesien determinan $\left(\mathrm{R}^{2}\right)=0,340$ menunjukkan pengaruh kadmium $(\mathrm{Cd})$ terhadap suhu hanya sebesar $34,0 \%$ dan sisanya $66,0 \%$ ditentukan oleh faktor lain yang tidak dianalisis pada penelitian ini.

DO merupakan parameter penting dalam analisis kualitas air dan juga penentuan kandungan pencemaran logam berat didalam suatu perairan. Dimana nilai DO yang biasanya di ukur dalam bentuk konsentrasi ini menunjukkan jumlah oksigen yang tersedia dalam badan air. Ketika semakin besar nilai DO pada air, mengindikasikan bahwa air tersebut memiliki kualitas yang bagus serta tingkat pencemaran yang kurang. Jika nilai DO rendah, dapat diketahui bahwa air tersebut telah tercemar logam berat (Eshmat $d k k$, 2014).

\section{Kadmium (Cd) Air}

Hasil penelitian menunjukan kandungan kadmium (Cd) pada setiap stasiun pengambilan sampel air adalah sama yaitu masing-masing dengan nilai dibawah dari $0,003 \mathrm{mg} / \mathrm{L}$. Masing-masing nilai tersebut adalah nilai LOD (Limited of Detection). 
Tabel 1. Kandungan kadmium (Cd) pada Air Sungai Jeneberang

\begin{tabular}{ccc}
\hline \multirow{2}{*}{ Stasiun } & \multicolumn{2}{c}{ Kadmium $(\mathbf{C d})$} \\
\cline { 2 - 3 } $\mathbf{1}$ & Pertama & Kedua \\
$\mathbf{2}$ & $<0,003$ & $<0,003$ \\
$\mathbf{3}$ & $<0,003$ & $<0,003$ \\
$\mathbf{4}$ & $<0,003$ & $<0,003$ \\
$\mathbf{5}$ & $<0,003$ & $<0,003$ \\
Ambang Batas *) & $<0,003$ & $<0,003$ \\
\hline
\end{tabular}

*) Kriteria Mutu Air Berdasarkan Kelas III PP RI No. 82 (2001)

Sumber: Data Hasil Penelitian (2018).

Jika di lihat dari mutu standar kualitas air menurut kriteria mutu air berdasarkan kelas III PP RI No.82 (2001) tentang baku mutu kualitas air, logam berat kadmium (Cd) hanya 0,01 mg/L. Berdasarkan data yang diperoleh menujukan bahwa sepanjang aliran sungai Jeneberang sampai wilayah sekitar pantai Losari tidak tercemar kandungan logam berat kadmium $(\mathrm{Cd})$.

Terdapat dua sumber utama kontaminasi logam berat kadmium (Cd) pada lingkungan perairan yaitu melalui lapisan bumi dan aktivitas manusia (antropogenik). Logam berat kadmium dalam aktivitas manusia sering digunakan sebagai pewarna cat dan PVC/plastik sebagai katoda nikel. Sumber utama kontaminasi logam kadmium adalah daerah industri. Kadmium selalu bercampur dengan logam lain, terutama dalam pertambangan $\mathrm{Zn}$ dan $\mathrm{Pb}$ dengan kadar 0,2 sampai $0,4 \%$ sebagai hasil dari proses pemurnian $\mathrm{Zn}$ dan $\mathrm{Pb}$ (Darmono, 2001). Logam berat kadmium ini jumlahnya relatif kecil pada perairan sungai Jeneberang namun konsentrasinya dapat meningkat seiring karena proses dari pembuangan limbah industri. Sedangkan menurut penelitian yang dilakukan oleh Azhar dkk (2012) membuktikan bahwa logam Cd di perairan berasal dari hasil pestisida di sawah yang mengalir ke sungai dan juga tumpahan bahan bakar dari perahu nelayan.

\section{Kadmium (Cd) Tanah}

Hasil penelitian menunjukan kandungan kadmium (Cd) pada setiap stasiun pengambilan sampel tanah adalah sama yaitu masing-masing dengan nilai dibawah dari $0,10 \mathrm{mg} / \mathrm{kg}$. Masing-masing nilai tersebut adalah nilai LOD (Limited $O f$ Detection).

Tabel 2. Kandungan Kadmium (Cd) pada Tanah Sungai Jeneberang

\begin{tabular}{ccc}
\hline \multirow{2}{*}{ Stasiun } & \multicolumn{2}{c}{ Kadmium $(\mathbf{C d})$} \\
\cline { 2 - 3 } & Pertama & Kedua \\
\hline $\mathbf{1}$ & $<0,10$ & $<0,10$ \\
$\mathbf{2}$ & $<0,10$ & $<0,10$ \\
$\mathbf{3}$ & $<0,10$ & $<0,10$ \\
\hline $\mathbf{4}$ & $<0,10$ & $<0,10$ \\
$\mathbf{5}$ & $<0,10$ & $<0,10$ \\
\hline Ambang Batas $*)$ & & $\mathbf{0 , 5} \mathbf{~ m g / k g}$ \\
\hline
\end{tabular}


*) Kriteria Mutu Air Berdasarkan Ministry of State for Population and Enviromental of Indonesia, and Dalhousie, University Canada (1992)

Sumber: Data Hasil Penelitian (2018)

Jika di lihat dari mutu standar pada logam berat kadmium $(\mathrm{Cd})$ tanah yaitu 0,5 $\mathrm{mg} / \mathrm{kg}$. Berdasarkan data yang diperoleh menujukkan bahwa sepanjang aliran sungai Jeneberang sampai wilayah sekitar pantai Losari tidak tercemar logam berat kadmium (Cd) yang membahayakan untuk sampel tanah karena masih di bawah dari nilai ambang batas cemaran logam berat kadmium $(\mathrm{Cd})$ pada tanah.

Masuknya kandungan logam berat ke dalam tatanan suatu lingkungan diakibatkan oleh adanya aktivitas manusia seperti buangan industri yang mengandung logam berat. Logam berat selanjutnya akan terabsorpsi masuk ke dalam tanah sehingga akan terjadi penumpukan jika buangan industri atau limbah terus-menerus dibuang langsung ke tanah (Sudarwin, 2008).

Adapun faktor-faktor yang biasanya menyebabkan pencemaran logam berat di dalam tanah atau sedimen menurut Wardana (2004) yaitu limbah dari industri tekstil merupakan salah satu sumber pencemar logam berat terutama $\mathrm{Pb}, \mathrm{Cr}$, dan $\mathrm{Cd}$ yang dihasilkan dari proses pencelupan dan pewarnaan. Industri tekstil seringkali membuang limbahnya langsung ke perairan tanpa dilakukan pengolahan yang memadai sehingga langsung mencemari dasar perairan. Besarnya kandungan logam berat yang mengendap di dasar perairan pada daerah yang memiliki arus tenang akan jauh lebih tinggi jika dibandingkan perairan berarus kuat (Hutagalung $d k k, 1997$ dalam Emilia $d k k$, 2013). Namun, pada perairan sungai Jeneberang memiliki kandungan logam berat yang masih jauh dibawah nilai ambang batas yang menandakan bahwa tanah atau sedimen didasar perairan belum terlalu terkontaminasi.

\section{Kadmium (Cd) Ikan}

Kandungan $\mathrm{Cd}$ yang paling tinggi pada stasiun 1 yaitu $0,0145 \mathrm{mg} / \mathrm{kg}$, kemudian pada stasiun 2 yakni $0,023 \mathrm{mg} / \mathrm{kg}$ serta pada stasiun 3 yakni $0,0093 \mathrm{mg} / \mathrm{kg}$. Untuk stasiun 4 dan stasiun 5 memiliki nilai yang sama yaitu kurang dari $0,10 \mathrm{mg} / \mathrm{kg}$. Begitupun dengan pengambilan sampling kedua memiliki nilai yang sama di setiap stasiun yaitu $0,10 \mathrm{mg} / \mathrm{kg}$.

Tabel 3. Kandungan Kadmium (Cd) pada Ikan Sungai Jeneberang

\begin{tabular}{|c|c|c|}
\hline \multirow[t]{2}{*}{ Stasiun } & \multicolumn{2}{|c|}{ Kadmium (Cd) } \\
\hline & Pertama & Kedua \\
\hline 1 & 0,0145 & $<0,10$ \\
\hline 2 & 0,0123 & $<0,10$ \\
\hline 3 & 0,0093 & $<0,10$ \\
\hline 4 & $<0,10$ & $<0,10$ \\
\hline 5 & $<0,10$ & $<0,10$ \\
\hline Ambang Batas *) & \multicolumn{2}{|c|}{$0,10 \mathrm{mg} / \mathrm{kg}$} \\
\hline
\end{tabular}


Berdasarkan nilai ambang batas logam berat kadmium (Cd) pada biota laut yaitu $0,10 \mathrm{mg} / \mathrm{kg}$. Dengan melihat nilai ambang batas kandungan kadmium (Cd) tersebut, sampel ikan yang diperoleh dari sungai Jeneberang masih di bawah batas ambang dengan kata lain ikan tersebut masih layak untuk dikonsumsi. Hal ini sesuai dengan WHO/FAO dimana nilai ambang batas kadar kadmium (Cd) yang diperbolehkan dalam tubuh ikan dan tumbuhan laut yang dapat dikonsumsi manusia yakni 0,1 ppm.

Menurut Darmono (2001), Adapun hal yang menyebabkan ikan tidak terkontaminasi karena ikan adalah jenis organisme air yang dapat bergerak dengan cepat di dalam air. Karena dapat bergerak dengan cepat, ikan mempunyai kemampuan menghindarkan diri dari pengaruh polusi, sehingga ikan-ikan di perairan tidak mudah terkontaminasi oleh logam-logam berat yang ada di dalam air. Namun demikian, pada ikan yang hidup dalam habitat yang terbatas (seperti sungai, danau dan teluk) akan sulit menghindarkan diri dari pencemaran. Sebagai salah satu akibat terakumulasinya unsur-unsur pencemar termasuk logam berat $\mathrm{Cd}$ ke dalam tubuh ikan (Murtini \& Novalia, 2007). Ikan merupakan salah satu yang bisa dijadikan indikator terjadinya pencemaran logam berat. Jika di dalam tubuh ikan telah terkandung kadar logam berat yang tinggi dan melebihi batas normal yang telah ditentukan dapat digunakan sebagai indikator terjadinya suatu pencemaran dalam lingkungan (Sundari $d k k, 2016$ ).

Adanya kandungan logam berat $\mathrm{Cd}$ pada ikan disebabkan karena air yang sudah terkontaminasi dengan limbah menyebabkan ikan yang hidup dalam air tersebut terkontaminasi pula dengan logam berat (Syarifudin $d k k$, 2017). Logam berat masuk ke dalam jaringan tubuh biota laut melalui beberapa jalan yaitu saluran pernafasan (insang), saluran pencernaan (usus, hati, ginjal) (Setiawan, 2013). Jika ada logam berat dalam perairan, maka akibat adanya logam berat ini yaitu mengakibatkan kerusakan pada biota di dalam air bila secara terus menerus biota ini mengakumulasi logam berat tersebut (Teheni \& Syamsidar, 2016).

Kadar logam berat yang terdapat dalam tubuh organisme perairan seperti ikan lebih tinggi jika dibandingkan dengan kadar logam berat yang terdapat dalam lingkungan hidupnya (Istarani \& Ellina, 2014). Terkhususnya pada ikan apabila kadar logam berat kadmium melewati nilai ambang batas maka akan menghambat pertumbuhan ikan serta mengakibatkan ikan menyebabkan toksik. Apabila ikan ini dikonsumsi oleh manusia maka akan meyebabkan keracunan. Namun, pada penelitian ini cemaran logam berat kadmium (Cd) pada ikan masih dibawah nilai ambang batas yang berarti bahwa ikan di perairan sungai Jenberang masih layak untuk dikonsumsi.

\section{Simpulan}

Berdasarkan hasil penelitian kualitas air sungai Jeneberang serta cemaran logam berat kadmium (Cd) baik pada air, tanah dan ikan masing-masing tidak memberikan pengaruh nyata. Nilai logam berat kadmium (Cd) pada setiap parameter berada di bawah batas ambang kualitas air dengan (Do) yaitu 6,24-7,2 $\mathrm{mg} / \mathrm{L}$. Sehingga ikan yang diperoleh dari sungai Jeneberang masih aman untuk dikonsumsi. 


\section{Daftar Pustaka}

Al Husainy, Irfan., Darma B. \& Rusdi L. 2014 Analisis Kandungan Logam Berat Timbal $(\mathrm{Pb})$ di Air dan Sedimen Pada Aliran Sungai Percut Provinsi Sumatera Utara. Jurnal Aquacoastmarine 5(4): 23-32.

Amansyah, M. \& Alwiyah N. S. 2014. Analisis Kandungan Logam Berat pada Kerang Ana Dara dari Daerah Hilir Sungai Jeneberang. Al-Sihah : Public Health Science Journal 6 (2): 85-98.

Anggriana, Dwi. 2011. Analisis Cemaran Logam Berat Timbal (Pb) Dan Kadmium (Cd) Pada Air Sumur di Kawasan PT. Kima dengan Metode Spektrofotometri Serapan Atom (SSA). Skripsi. FIK. Universitas Islam Negeri Alauddin. Makassar.

Ayyub, F. R., A. Rauf, \& A. Asni. 2018. Strategi Pengelolaan Ekosistem Terumbu Karang di Wilayah Pesisir Kabupaten Luwu Timur. Jurnal Pendidikan Teknologi Pertanian. Vol. 4 Maret Suplemen :S56-S65.

Azhar, H., Ita W. \& Jusup S. 2012. Studi kandungan Logam berat $\mathrm{Pb}, \mathrm{Cu}, \mathrm{Cd}$, Cr pada Kerang Simping (Amusium pleuronectes), Air dan Sedimen di Perairan Wedung Demak serta Analisisis Maximum Tolerable Intake pada Manusia. Journal of Marine Research 1 (2): 35-44.

Darmono. 2001. Lingkungan Hidup dan Pencemaran. Jakarta: Penerbit Universitas Indonesia.

Effendi, H. 2003. Telaah Kualitas Air Bagi Pengelolaan Sumber Daya dan Lingkungan Perairan. Yogyakarta: Kanisius.

Emilia, I., Suheriyanto \& Zazili Hanafiah. 2013. Distribusi Logam Kadmium dalam Air dan Sedimen di Sungai
Musi Kota Palembang. Jurnal Penelitian Sains 16 (2): 59-64.

Eshmat, M. E., Gunanti M. \& Boedi S. R. 2014. Analisis Kandungan Logam Berat Timbal $(\mathrm{Pb})$ dan Cadmium (Cd) pada Kerang Hijau (Perna Viridis L.) di Perairan Ngemboh Kabupaten Gresik Jawa Timur. Jurnal Ilmiah Perikanan dan Kelautan 6 (1): 101-108.

Happy, A. R., Masyamsir \& Yayat D. 2012. Distribusi Kandungan Logam Berat $\mathrm{Pb}$ dan $\mathrm{Cd}$ Pada Kolom Air Dan Sedimen Daerah Aliran Sungai Citarum Hulu. Jurnal Perikanan dan Kelautan 3 (3): 175-182.

Istarani, Festri \& Ellina S. P. 2014. Studi Dampak Arsen (As) dan Kadmium (Cd) terhadap Penurunan Kualitas Lingkungan. Jurnal Teknik Pomits 3 (1): 53-58.

Mahyudin, Soemarno \& Tri Budi Prayogo. 2015. Analisis Kualitas Air dan Strategi Pengendalian Pencemaran Air Sungai Metro di Kota Kepanjen Kabupaten Malang. J-PAL 6 (2).

Ministry of State for Population and Enviromental of Indonesia, and Dalhousie, University Canada. 1992. Environmental Management in Indonesia. Report of Soil Quality Standars for Indonesia.

Monoarfa, Winarni. 2002. Dampak Pembangunan Bagi Kualitas Air Di Kawasan Pesisir Pantai Losari, Makassar. Sci \& Tech 3 (3): 37-44.

Murtini, J. T. \& Novalia R. 2007. Kandungan Logam Berat pada Ikan, Air dan Sedimen di Waduk Saguling Jawa Barat. Jurnal Pascapanen dan Bioteknologi Kelautan dan Perikanan 2 (2): 153-159.

Nur, A. I., H. Syam, \& Patang. 2016. Pengaruh Kualitas Air Terhadap Produksi Rumput Laut (Kappaphycus alvarezii). Jurnal Pendidikan 
JPTP Jurnal Pendidikan Teknologi Pertanian teknologi Pertanian. Vol. 2 No 1: 2740.

Nurdin, H. P. 2009. Kajian Akumulasi Logam Berat timbal (Pb) dan Kadmium (Cd) Pada Spongelaut Xestospongia Testudiaria Sebagai Bioakumulator di Perairan Pulau Kayangan dan Pulau Samalona. Skripsi. Program Studi Ilmu Kelautan Fakultas Ilmu Kelautan dan Perikanan Universitas Hasanuddin. Makassar.

Nurfitriani, W. Caronge, \& Ernawati, S. Kaseng. 2017. Keanekaragaman Gastropoda di Kawasan Hutan Mangrove Alami di Daerah Pantai Kuri Desa Nisombalia Kecamatan Marusu Kabupaten Maros. Bionature. Vol. 18 No. 1: 71-79.

Patang. 2009. Komposisi Spesies, Pola Sebaran dan Kerapatan Tegakan Vegetasi Padang Lamun (Seagrass Beds.) di Pesisir Pantai Kabupaten Pangkep. Politeknik Pertanian Negeri Pangkep.

Patang. 2014. Use Of Antibiotic And Probiotic Controlling Water Quality, Growth And Suvival Of Shrimp Lanae Penaeus Monodon Fabricius. Asian Jr. of Microbiol. Biotech. Env. Sc. Vol. 16, No. (2) : 241-245.

Peraturan Pemerintah Republik Indonesia No. 82 Tahun 2001. Tentang Pengelolaan Kualitas Air dan Pengendalian Pencemaran Air.

Rachmaningrum, M., Eka W., \& Kancitra P. 2015. Konsentrasi Logam Berat Kadmium (Cd) pada Perairan Sungai Citarum Hulu Segmen DayeuhkolotNanjung. Jurnal Rekayasa Lingkungan 1(3) : 1-11.

Setiawan, H. 2013. Akumulasi dan Distribusi Logam Berat pada Vegetasi Mangrove di Perairan Pesisir Sulawesi Selatan. Jurnal Ilmu Kehutanan 7 (1).
Volume 5, 2019

Setiawan, Heru. 2014. Pencemaran Logam Berat Di Perairan Pesisir Kota Makassar Dan Upaya Penanggulangannya. Info Teknis EBONI 11 (1): 1-13.

SNI 7387:2009 Batas Maksimum Cemaran Logam Berat dalam Pangan. Badan Standarisasi Nasional.

Sudarwin. 2008. Analisis Spasial Pencemaran Logam Berat (Pb dan Cd) pada Sedimen Aliran Sungai dari Tempat Pembuangan Akhir (TPA) Sampah Jatibarang Semarang. Tesis. Semarang: Program Pascasarjana Universitas Diponegoro.

Sundari, D., Miko H. \& Suharjo. 2016. Kandungan Logam Berat dalam Bahan Pangan di Kawasan Industri Kilang Minyak, Dumai. Buletin Penelitian Sistem Kesehatan 19 (1): 55-61.

Syamsuddin, Rajuddin. 2014. Pengelolaan Kualitas Air: Teori dan Aplikasi di Sektor Pertanian. Makassar: Pjar Press.

Syarifuddin, A. R. Maddusa, S. S. \& Akili, H. R. 2017. Analisis Kandungan Logam Berat pada Air, Ikan, Kerang dan Sedimen di Aliran Sungai Tondano Tahun 2017. Fakultas Kesehatan Masyarakat Universitas Sam Ratulangi. Manado.

Taufieq, N. A. S. 2009. Analisis Tingkat Kekeruhan Air DAS Jeneberang Sebagai Sumber Air Baku Pam Somba Opu. Jurnal Chemica 10 (1): 44-49.

Teheni, M. T. \& Syamsidar M. S. 2016. Penentuan Kadar dan Distribusi Spasial Logam Berat Kadmium (Cd) pada Rumput Laut Asal Perairan Kab. Takalar dengan Metode SSA (Spektrofotometer Serapan Atom). Fakultas Sains dan Teknologi UIN Alauddin Makassar.

Wanna, M., S. Yanto, \& Kadirman. 2017. Analisis Kualitas Air dan Cemaran 
JPTP Jurnal Pendidikan Teknologi Pertanian

Logam Berat Merkuri (Hg) dan Timbal (Pb) pada Ikan di Kanal Daerah Hertasning Kota Makassar. Jurnal Pendidikan Teknologi Pertanian. Vol.3. September Suplemen : S197-210.

Wardana, W. A. 2004. Dampak Pencemaran Lingkungan. Edisi Revisi. Yogyakarta: Penerbit Andi.

Yuningsih, H. D., Prijadi S. \& Sutrisno A. 2014. Hubungan Bahan Organik dengan Produktivitas Perairan pada Kawasan Tutupan Eceng Gondok, Perairan Terbuka Dan Keramba Jaring Apung di Rawa Pening Kabupaten Semarang Jawa Tengah. Diponegoro Journal of Maquares Management of Aquatic Resources 3 (1): $37-43$ 
JPTP Jurnal Pendidikan Teknologi Pertanian

Volume 5, 2019 